\title{
Forage for Military Purposes: Lecture II
}

\section{George Fleming Principal Veterinary Surgeon of the Army C.B., LL.D.,}

\section{F.R.C.V.S.}

To cite this article: George Fleming Principal Veterinary Surgeon of the Army C.B., LL.D., F.R.C.V.S. (1889) Forage for Military Purposes: Lecture II, Royal United Services Institution. Journal, 33:149, 855-876, DOI: 10.1080/03071848909418086

To link to this article: http://dx.doi.org/10.1080/03071848909418086

\section{曲 Published online: 11 Sep 2009.}

\section{Submit your article to this journal $₫$}

Џ Article views: 3

Q View related articles $₫$ 
Fridas, Juno 14, 1889.

Gexfral Sir C. P. BEAUCHAMIP WALKFR, K.C.B., Vice-

FORAGE FOR MILITARY PURPOSES.

LECTURE II.

B5 Georae Flewisa, C.B., LL.D., F.R.C.V.S., Principal Veterinary Surgeon of the Arms.

In the last lecture which I had the honour and the privilege of delivering before you on "Forage for Military Parposes," I dealt more cspecially with the different kinds of forage in use in the rarious armies abroad, the concentrated foods which have been proposed or used from time to time, and the forage which, after all, has been found best adapted for active service, i.e., that which has been com. pressed. I dwelt strongly on the necessity for the forage used in the field being that to which the horses have been accustomed, and pointed ont the inconrenience, oftentimes danger, in suddenly changing from one kind to another, particularly when horses are undergoing sovere esertion, and are exposed to the weather. I showed that concentrated, or specially prepared, and what might bo tormed "artificial food," was not suitable for horses during war, and that quantity as well as quality was necessary in order to meet physiological demands. Mluch experimental investigation, no less than every day's practical experience, has demonstraled that concentrations and essences, though useful in tho hospital stables, are of little value in sustaining the energies of lealthy, hard-working horses; and that bulk is an important factor in allaying the pangs of hanger, and producing that contentment and satisfaction which leads to good digestion, and restoration to the system of that which has been expended in exertion.

'Tho nataral food of tho horse, in Western conntries at least, and which is oats and hay, appears to be sufficiently concentrated; and as it forms the staplo aliment all tho ycar round, it is that which should, whenever possible, be allowed on actire service. The only preparation it needs-always premising, of course, that the quality is good-is that which best adapts it for conveyance, kecping, and ready issue, without waste either in transport or during consumption. And I rentured to insist upon this preparation being limited to crushing the grain, so as to render it ensier of mastication (a great benefit to a 
tired horse), and more readily and completely digested (a desideratun when the organism is fatigned, and assimilation is consequently weakened); while its being firmly compressed into cakes of a certain weight renders its transport an casy and economical matter, its preservation for long periods, even when exposed to the weather, certain, and its distribution very simple.

The same was said with regard to the hay, which, next to the grain, is so necessary as an article of food. In the field, long hay, even when compressed into compact trusses, is troublesome, and not economical. It is easily damaged by the weather, there is mnch waste in distribution, and still more in feeding it to the horses when they are on picket lines, and especially when the weather is wet or windy; as then it is either trodden into the mnd or blown away. In order to economize space in transport, render it capable of being kept for an indefinite period, readily issued, and easily consumed by the horses without waste, I remarked that it might be "chopped" or cnt into short pieces, firmly compressed into cakes of a given weight, and -as with the grain cakes- - certain number of these packed into bales. Tho grain and hay could be given to the horses, mixed, in a convenient-sized nosebag, and thus all waste would be avoided; while masticntion being mado so much easier and quicker, the horses would have more time for rest.

Other advantages attending the provision of this kind of portable forage I alluded to, and among them $I$ included that of a smaller quantity of this food being equivalent to the ration of ordinary forage, i.e., uncrushed grain eaten out of the present pattern of nosebag, and long has eaten off the ground. The diminution might bo fixed at a pound, or at least half a pound, per ration. But this matter of ration leads to the consileration of the lecture of to-day, which is intended to deal with the allowance of forage necessary to maintain troop horses in a fit state of health and vigour, so as to meet the requirements of service, either in garrison or the field. On activo.service, more especially, is this an important matter, as it is absolutely necessary that horses should be kept in the highest state of efliciency, and ready for the sererest and most prolonged trials, or the most sudden cmergencies; while, at the same time, there may be grave difficulties to be contended with in procuring an adequate supply of forage for this purpose.

The question as to what amount of forage should constitute a suitable ration for military horses is not so easily dealt with as might be imagined, for in discussing it several circumstances have to be taken into account-such as the size of tho horses; the season of the year and the climate; the work tho horses have to undergo; whether they are protected from, or exposed to the weather; whether they aro accustomed to privations; or hare been regularly and well fed, \&c.

Of course, a certain amount of food nust be allowed horses to maintain them in health, even when they do not perform any work; but bejond this allowance there must be an increase in proportion to the energy expended in exertion, though this can only be up to a certain point; for if, this expenditure becomes grenter than the 
gsstem can sustain, then an unlimited qunntity of food, eren though it be of the most nutritious kind, will not cnable them to withstand the strain upon the vital fanctions.

It might, therefore, be laid down as an axiom, and, indecd, it is gencrally so recognized, that the quantity of food bejond a certain allowauce for" what has been well termed "internal" work, and which should be proportionate to the size of the animals, should be suffi. cient. to meet the demands of "exterual" work and the special circumstances in which troop horses may be placed. In our army, there is a uniformity in this matter which reduces the question of feeding to the greatest simplicity, though it inust be confessed that it is scarcely in harmony with reason or experience. The fornge ration is nerer raricd all the ycar round, no matter how young or hor old the aniwals are, how heary or how light the work may be (with oue or two exceptions to be presently mentioned); nnd large horses weighing 1,200 or $1,400 \mathrm{lbs}$. receive the same quantity as those weighing $800 \mathrm{lbs}$. This ration is, as yon aro aware :-

If in quarters, oats $10 \mathrm{lbs}$, hay $12 \mathrm{lbs}$., straw $8 \mathrm{lbs}$.

If in encampments, oats $12 \mathrm{lbs}$., hay 12 lbs.

If emplojed on draught work, 2 lbs. onts extra.

The extra issue is allowed to horses of the Army Service Corps drawing wagons at a trot; and during the winter months only, for all other dranght horses when emploged on covtinuous draught work for in period of at least five hours a diay.

An extra issue of 2 lbs. of onts, in addition to the ordinars ration in quarters or in cucampments, is allowed to draught horses of the Army Serrice Corps when these are 10 hands high aud upwards.

In Continental Armies, the allowance of forage is systematically adjusted to the size of all the horses and the nature of their work.,

In the German $\Lambda \mathrm{rmy}$, for instance, there are four scales of fornge rations, the difference between them consisting chied $f$ in the awount of oats. There is, first, the heary ration, which consists of 11 lbs. $7 \frac{3}{4}$ ozs. of oats; sccond, the ration for Light Cavalry of the Guard, which is $10 \mathrm{lbs}$. $15 \mathrm{ozs}$; third, the medium ration, which is $10 \mathrm{lbs}$. $11 \frac{1}{3}$ ozs.; and fourth, the light ration, which is only 9 lbs. $13 \frac{1}{2}$ ozs. .

The allowance of hay is 5 lbs. $7 \frac{1}{2}$ oz., and of straw 7 lbs. $10 \frac{1}{2}$ ozs.

These rations are issued as follows :-

The beary ration is allowed to horses of General Officers, the General State, Adjutants, Officers of the TVar Ministry, Cuirassier and Guard Inancer- Regiments, Mlilitary Riding School, Guard Horse Artillery and Field Officers of Guard Ficld Artillers, all Artillers draught horses, those of the Gendarmerie and Intendance, and Transport draught horses. I'roop horses of the Gardes du Corps Regiment leccire at all times $1 \mathrm{lb}$. $1_{4}^{\frac{1}{4}}$ ozs. of oats, and $3 \mathrm{lbs}$. $4 \frac{1}{2}$ ozs. of liay extra.

The second scale is giren to the Light Caralry of the Guard, Guard Dragoons, and Guard Hussars.

The medium ration is for the lancer regiments of the line. 
The light ration is for all other troops and the horses of Oftieers not specified.

The abore are termed the "Garrison Rations," and are only diawn for horses on the strengtll; the threo or four extra horses in each squadron, battery, and company of 'l'ransport have to be fed on what can be saved from the fornge of the olhers. It is not compulsory to give the horses their full rations daily, but a portion mas be reserved tor times when work is henvier than usual.

On the line of march the ration is increased as follows:-

Heary ration to 13 lbs. $3 \frac{3}{6}$ ozs. onts.

Light Guard Cavalry ration to 11 lbs. $7 \frac{3}{4}$ ozs. oats.

IIedium ration to 11 lbs. $4 \frac{1}{4}$ ozs. oats.

Light mition to $10 \mathrm{lbs}$. $6 \frac{1}{\mathrm{q}}$ ozs. oats.

The heary ration of oats is accompanied by 3 lbs. $4^{\circ}{ }^{\circ}$ ozs. cach of hay and straw for feeding; the other rations laving 3 lbs. 4 ozs. of hay, and 3 lbs. $13 \frac{1}{4}$ ozs. of straw for the same purposes, as litter is provided in the billets.

In the ficld this ration is increased all round by $S_{\frac{3}{4}}$ ozs. of oats, each horse then carrying what is called "the iron ration of onts"-nearly $14 \mathrm{lb}$. the hears ration, orer $12 \mathrm{lbs}$. the second, $11 \mathrm{lbs} .13 \mathrm{ozs}$. the third, and $11 \mathrm{lbs}$. 1 oz. the light mation.

During railway transport, cach horse is allowed 3 lby. $4 \frac{1}{2}$ ozs. of hay, and 2 lbs. 3 ozs. of straw to lay on the floor and raup of the wingon. If the journey lasts longer than eight hours, 6 lbs. 9 ozs. of hity is allowed extra for every twenty-fonr hours.

During Army Corps manouvres and Cavally Division exercises for a period of four weeks, the following rations are allowed :-

For Cuirassiers or Horse Artillery draugint horses, 12 lbs. 14! ozs. onis.

lior other line cevalry regiments and horso artillery riding horses, 11 lbs. $7 \frac{3}{3}$ ozs. oats.

As on the march, 3 lbs. 4 ozs. of has and 3 lbs. $13 \frac{1}{4}$ ozs. of straw are allowed.

'I'brec-year-old remoants at the lRemount Depôts receire:-

Oats, 6 lbs. 9 ozs.

Hay, 10 lbs. 15 ozs.

Straw, 13 lbs. 2 ozs.

For three or four months of the year they are put on grecn food, but the transition to and from this is gradual.

In the French Arms there is a similar gradation in the scale of fornge ration, according to the arm of the Service and the kind of work performed. 'The light cavaley (infuntry Officers' horses are included in this categrory) allowance fer lorse per diem is-onts nhout $8 \%$ lbs., hay 83 lbs., straw $5 \frac{3}{4}$ lbs. in garrison; on the march it is iv lbs. oats, with the same quantity of hay and straw as in garrison; at manceures, if the horses are in barracks they receire the samo mation of oats as in garrison, with $6 \frac{3}{4}$ lbs. hay and about 9 lbs. straw, but if in birouac then the rntion is the same as for the march; while 
on a war footing it is $10 \frac{3}{4} \mathrm{lbs}$. oats, $6 \frac{3}{4} \mathrm{lbs}$. has, and $4 \frac{3}{4} \mathrm{lbs}$. stram. The line cavalry (tho horses of engineer and infantry Oficers are on this scale) receivo in garrison $10 \mathrm{lbs}$. onts, $6 \mathrm{a}$ lbs. of liay, and $9 \mathrm{lbs}$. straw; on the march 11 libs. oats, and 11 lbs. bay and striw; at manceurres, if in barracks the ration is the same as in garrison, if in birounc it is as on the line of march; while on a war footing it is nearly 11 lbs. oats, 9 Jbs. hay, and $4 \frac{1}{2}$ lbs. straw. The reservo cavalry includes the horses of the Staff, Intendance, Staff of Artillers, and of Fnerinecrs, and Auxiliary Transport. The ration in garrison is-oats $11 \frac{1}{4}$ lbs., haty 9 lbs., straw 9 lbs.; on the march it is-oats 12 lbs., hay and straw $11 \mathrm{lbs}$; on manouvres, if in batracks it is the same as in garuison, and if in bivounc the same as on the march; on a war footing the allowance of oats is 13 lbs., hay 9 lbs., straw $4 \frac{1}{3}$ lbs. For artillery horses-diaught and saddle-the garrison ration is $10 \frac{3}{4}$ lhs. oats, hny 9 lbs., straw 9 lbs.; on the march it is $12 \mathrm{lbs}$. oats, 11 lbs. has; and the same of straw; on manourres, if in barracks it is the same as in garrison, if in bivouac, tbe marching allowance is given; the war ration is nearly 13 lbs. cats, 9 lbs. hay, $4 \frac{1}{2}$ lbs. straw.

In the Russian Army the daily ration during peace is as follows:-

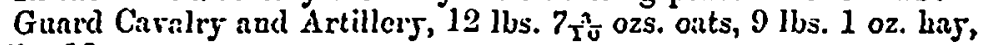
3 lbs. 10 ozs. straw.

Lino cavalry, artillerg, and engincers, 9 lbs. 5 ly ozs. onts, and the same hay and straw as abore.

Transport draught horses, 7 lbs. $12 \frac{13}{20}$ ozs. oats, 18 lbs. 2 ozs. has. ${ }^{1}$

In the regiments and batteries of the Guard, this allowance is giren all the ycar round, but in other corps it is only issued for eleven months, the lowses being turned ont to grass, and receive no more than 13 lbs. 91 ozs. of hay for one month after the manceurres.

If necessary, barley way be substituted for oats, wcight for wcight, and has can replace onts in the proportion of 4 lbs. $8 \frac{1}{2}$ ozs. of hay for 3 lbs. $1 \frac{t}{s}$ ozs. oats. In war, the abore rations aro issued, with the addlition of 3 lbs. 10 uzs. of oats; aud in licu of straw 4 lbs. 8 s ozs. of hay aro given. Thus, the forage ration of a line cavalry regiment during war is $12 \mathrm{lbs}$. $15 \mathrm{~d}$ ozs. of oats, and $13 \mathrm{lbs}$. $9 \frac{1}{2}$ ozs. of hay.

lyom this statement, you will see that in the great armies of the Coutinent, close attention has been paid to the quantity of fornge required in each arm of the Service, to ensure physical fitness in peaco and in war; and you will also gather that in our Army this subject has cridently not received the notice it descrres. Our horses are cither underfed while they are performing hard work, or they are orerfed when this is light; and if the ration is suffeient for large horses, it must be more than sufficient for small ones. I an certainlyof opinion that the whole subject of forage for our troop horses necds investigation; and in view of the fact that the allowance is not

I Since this lecture was delirered, Major J. Tolfe Mrurras, Intelligence Branch, War Oflice, has had the goodness to inform me that the ration of forage for the Tuain horses of the Russian Arms has been considerably modified, as he had already pointed out in this Journal for 18S6, y. 1033. Insted of the claily ration beind as aborc, it is now 13 lbs. oats and $13:$ lb3. lag - a grcatls improrcl ration ccrtainly. -F.G. 
properly apportioned between light and heary horses, or with refer. ence to the work done, and that it is generally inferior to that of other European armies, especially that of Germany, I think the time has arrived when this inquiry should be made. In this inquiry the quality of the forago should not be overlooked; the present contract weight of onts is too low, and should be altered. No oats for armyhorses should be less than $40 \mathrm{lbs}$. per bushel.

We must recognizo tho fact that to feed liorses well may bo oxpen. sive, but to feed them badls, even in pence-time, is nuch more so; while to nourish them insafticiently during war may mean heary loss or:disaster.

It is not always easy to combine economy, or rather cheapness, with efficiency of a permanent bind. With armies which must always be prepared for war at short notice, and wust be rapidly mobilized, the mounted corps should require little, if ang preparation, so far as their horses are concerned; for mnless they are kept always in a fit state for the ficld by good fecding and training, there may not be time to prepare them-and some tiwe is uceded to do this-when the urgent moment arrives. This necessity must be 2ecognized as applying more especially to the caralry, as it has to encounter the first strain in warfaxc; and the army which has its horses in the fittest state will, probably, be that which will gain suecesses at first, and early victories often decide campaigrs.

I would not have it inferred that borses should be rationed to the same extent when performing light work-as is often the case at outquarters in winter-as during the summer mancouvres; they shonld be fed to a degree equal to the labour exacted from them. If a horse is not fed in proportion to the work inposed upon him, compensation Las to be made from his muscles; so that he partially cousumes them, ind consequently loses weight. If a sufficiency of food is not supplied in tiule, with this loss of weight there is diminution of energs as the ruuscular tissue disappears, and at last cxhaustion ensues.

On the contrary, if the allowance of food is greater than is required, some of it will not be consuned, and a portion will bo expended in laying on useless fat-mhile the state of plethora so engendered will be accompanied by a tondency to discasc, and an excitability and restlessness which will lead to a large incrcase in the list of crsualtics.

The weight of horses is, to some extent, a criterion by which a conclusion may be arrived at as to whether they are sufficiently fed. Loss of weight accompanies an insuflicient supply of food, and this loss is all the more marked and rapid as the deticiency is great and prolonged; it is all the greater if the food at the same time be of inferior quality.

We ore all familiar with the change wrought in the appearance of horses which hare undergone the fatigues of a severe drill season, without any increase in their forage rntion; and if their weight were to bo compared with that which it was before the season commenced, there would be found a considerable diminution. I do not know if this has erer been accurately tested in onr Army, but it appears that 
it has been ascertained on, at least, one occasion in one. of the Continental armies-that of Austria. In a military journal of that conntry (Oesterreich-Ungarische Welhr-Zeitung), published in October, 1887, there is a report upon the condition of artillerg horses belonging to a Division, during the annaal manceurres. The artillery Commandant had the horses weighed before they marched on $A$ ugust $20 \mathrm{th}$, and again on their return to quarters on September 7 th-i period of eighteen dass. Before marching, the average weight of the horses was :-

In the first battery .............. 974 lbs.

In the second battery ............. $967 \mathrm{lbs}$

On their return, the average weight was :-

In the first battery .............. 94a lbs.

Jn the second battery ............. $943 \mathrm{lbs}$.

The arerage loss of weight was therefore 29 lbs. and 24 lbs. The work performed dnring the eighteen dass was on an average from 18 to 22 miles per dien.

But we must not forget that the weight test is not altogether a reliable one, unless we take into onr consideration, at the same time, the condition of the horses-that is, their energy and cndurance. Horses idle and fat, and therefore not well-fitted for hard work, will weigh hearier than the sano horses in good hard condition, and capable of undergoing serere toil. A race-hurse, in training, loses weight, but gains in vigour.

I do not consider our caralry horses, in peacc-time, badly fed, nor jet orerfed; though it rould be an adrantigo if the ration could bo so amended as to allow of more grain being given during the hard work period, and less during the easy work period. For the beavy horses of artiller5, Rogal Finginecrs, and Army Serrice Corps, tho allowance certainly appears insufficient, if size and wight are to be estimated in alimentition. And in these this insufficiency is moro noticcable than in caraly during hears marches in tho drill scason. It should be the aim of those who have to arrango for the feeding of horses, and more especinlly during active service, that the ration should be such as to maintain uudiminished weight, and increased energy, if possible, under all circumstances. No economy can be more peruicious than underfeeding either soldiers or horses on a campaign. The better they are fed, the better they will perform.

As I have alreads stated, a certain aunount of good food is necessary to keep horses in health and condition, and if work is heavier than usual, or they aro exposed to bad weather, or have to undergo severe hardships, then additional forago should be giren, and in proportion to the increase in waste of the body through these exactions.

Horses for war should always be in a fit condition for the field, and therefore there ought not to be much variation in the forage ration cluring peace, except an increase to a small extent when the drills are beavy, and a decrease when the work is light. What the peace ration should be is shown in that laid down for each of tho principal Furopean armies. For our own Army, I have pointed out that size, 
work, and season are scarcely taken into consideration in fixing the ration. I think it would be advantageous to modify it to meet the requirements of these. If $10 \mathrm{lbs}$. of oats and $12 \mathrm{lbs}$. of hay are only sulficient for horses when in barracks at out-quarters, surely this allowance is insulficient when on the line of march or during the drill season!

Compared with the horses of cirilians, it cannot be said that, when andergoing a like amount of work, army horses reccive too much food. For the largest-sized draught horses which perform steady hard work for a number of hours during fire or six days in the week, the daily allowance of food for encls horse is about 18 lbs. hay and a small proportion of straw, cat into chaff, with $18 \mathrm{lbs}$. of oats, and a pound or two of peas or beans. The usual weight of dry food absolutely consumed by an average-sized, well-conditioned cart-horse moderately worked, recrularls fed, woll stabled, is from 29 lbs. to $3 \pm \mathrm{lbs}$. daily, of which the hay and straw should constitute about twofifths; and it is generally recogni\%ed that, no matter how nutritious it may be, less than $29 \mathrm{lbs}$. will not suffice to maintain the body in a fit state for work. In a stud of cart-horses in Liverpool, the following was the daily allownnce:-Mnizc, 10 libs.; Figsptinn beans or Camadian pens, 5 lbs.; oats, 2 lbs.; oatmeal and linseed, 1.3 lbs.; bran, $2 \cdot 1$ lbs.; has, 10.6 lbs.; roots and grass, 3 lbs. 'The maize, ard bcans or peas, with the bran and chopped hay, formed the basis of the usual food allowance. 'The oats and linseed were only used for sick or delicatefeeding horses. The oatmeal was made into gruel, of which each horse was allowed a drink on returning to his stable when the day's work was done. The roots and grnss wero given during the months it was considered advisable to use them. In autnmn and winter the grain was crushed and given uncooked, except a night feed of stcamed food two or threc times a reek. In spring and sumwer the grain was stenmed, but an occasional meal of dry food was allowed as a change. $A$ farther change, both in the quantity and proportion of the grain giren, was also frequently made, as conditions of weather or work appeared to require, but the autumn allowance was always considered the most invigorating. 'The bulk of the hay wns given in the form of chop or chaff with the grain, 2 or 3 lbs. of long hay being reserred for night cousumption. The best clover hay was always ased; and a small quantity of straw was sometimes chopped with the hay. The horses were of arerage size, moderately worked for six days, and onefourth of their number for about three hours on the seventh day; their condition was good.

A company emploring a large number of horses which draw hearily laden carriages, allows tho following ration for each horso per diem :- IIay, 16 lbs.; oats, 10 lbs.; beans, 5 lbs.; naize, 4 lbs.; lowa, 2 lbs.; total, 37 lbs. of food for every day. The hay is all chopped, and the grain crushed separately, then both are mixed before being giren to the horses.

Every Saturday night each horse is allowed a mash of linsced, mised with a small proportion of bian, boiled altogether, and given warm. When tho work is less, then less grain is giren. This, I 
beliere, is about the usnal quantity of food allowed for the larger, slow-paced, and stendily worked horses of civilians. For those of smaller size, but performing work at a faster pace-such as ommibus or tram-car horses $-\Omega$ smaller allowance of food is generally given. The following was the daily ration of the principal tram way companies in the United Kingdom not long ago. It may be observed, howerer, that this allowance raries in the proportions, according to the price of fornge in the market, and also sometimes according to the season :-

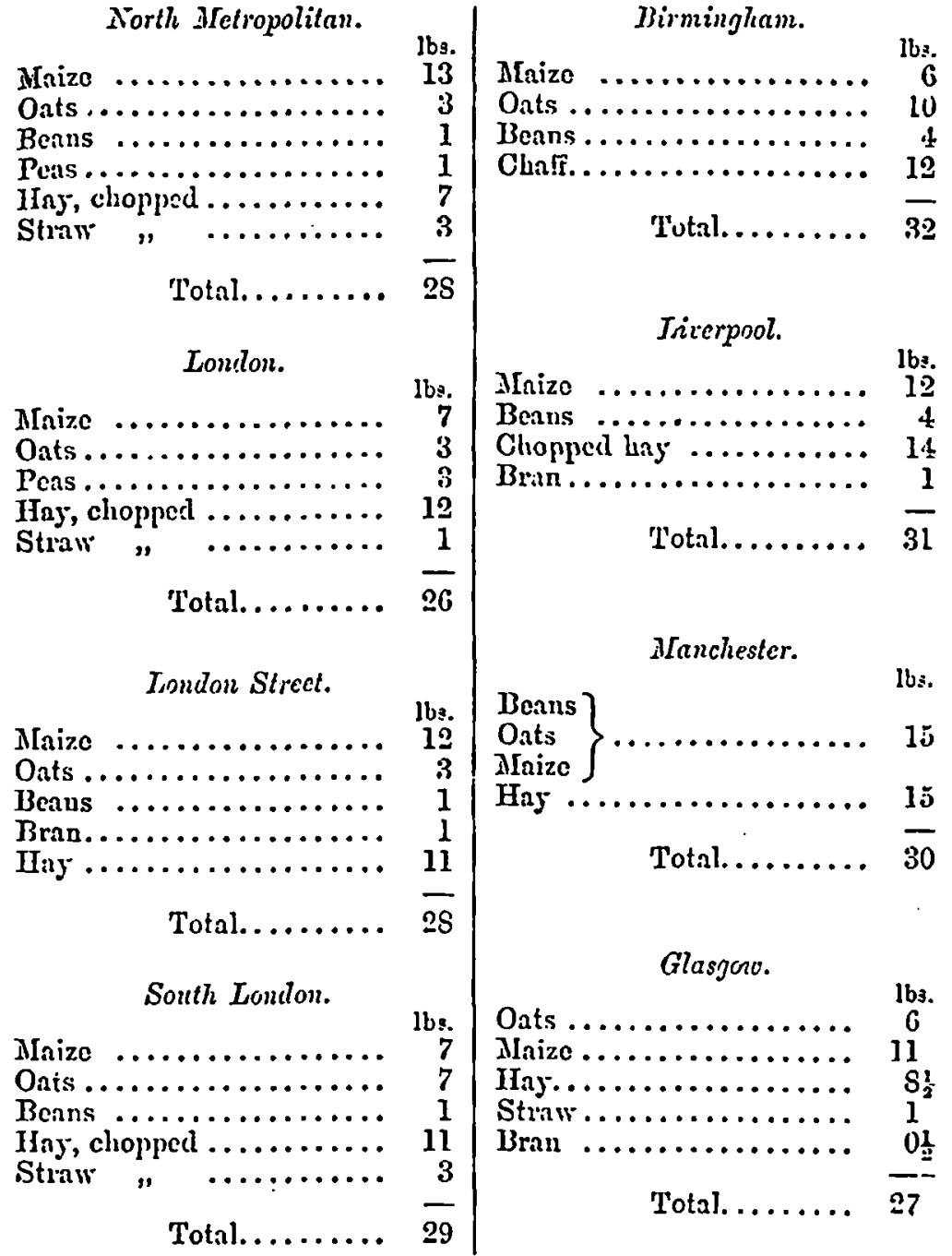




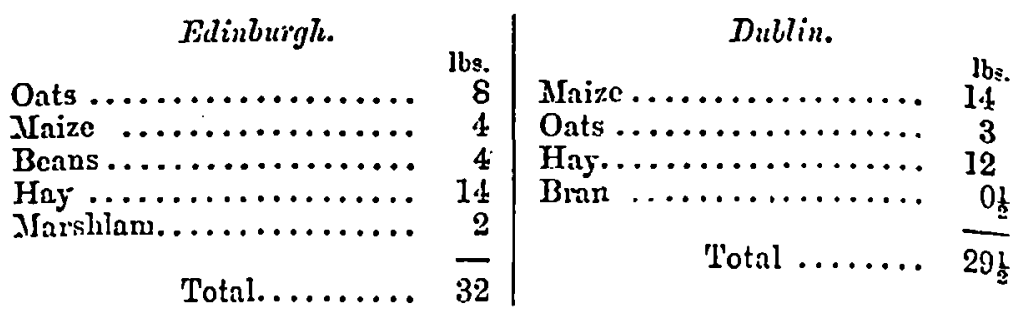

The work of these borses is performed at a trot of about 7 or 8 miles an hour, with rery frequent stopping and starting, and the average distance travelled is probably about 13 or 14 miles a day. Omnibus horses receire a similar ration, but the work is not so hervy.

In the pre-railway days, the horses which drew the mail and stage coaches were most liberally fed, and this liberality was well rewarded by the manner in which their work was done and the apvearanco they presented. "Nimrod" (Mr. Apperley), in his work on" "The Chase, the Turf, and the Road" (published in 1837), allnding to these hor'ses, says: "No horse lives so ligh as a coach-horse. In the langunge of the stable, his stomach is the mensure of his corn; he is fed all libitum. 'The effect of this is risible in two ways: first, it is surprising to see how soon horses gather flesh in this severe work, for there is none, so far as muscular exertion goes, more serere while it lasts; and, secondly, proprietors find that good flesh is no obstacle to their specl. but, on the contrary, operates to their advantage."

It is scarcely possiblo to compare dranght Army horses with those employed in this way in civil life, with respect to the amount of work they lare to undergo, and especially when the former are in the field. The demands of actire serrice are generall 5 of the most exacting and harassing kind. MIuch of the traction may have to be done where there are no roads, and often in heary ground; while with some corps-as the horse artillers, and cren the field artillers-the pace may require to be fast, and over vers dificult conntry. At the same time, tho horses generally have to remain without shelter and exposed to the weather, and receive but little attention, so far as grooning is concerned. Civilians' horses labour under none of these disadrantages in performing their scrvice. They work on mell-made roads, hare a definite amount of regular toil every day, are comfortably housed, cleaned, and degularly watered and fed by men who are themselve.s comforiable and esempt from danger, hunger, and exposure.

Army horses, therefore, employed in dranght should be at least as well fed as those of cirilians, more especially when the former are on active service. The grain ration slould be high, as libemal, in fact, as that of the conch horses mentioned by "Nimrod." 16 or $18 \mathrm{lbs}$. a-day per horse would not be too much, particularly in long and rapid marches, and even more should be given if the weather is at the same time unfavourable. If the grain is crushed, so much the hetter; indeed, for tired horses especially, all grain should bo so propared. 'l'! : 
anount of has in the field is a secondary consideration; as the grain is increased in quantity, the allowance of hay should be diminisled.

With regard to caralry horses the same remarks appls. The work of such horses is, in many respects, liko that of hunters, though it is performed in very different circumstances, and under disadrantages such as hunters never cxperience. Carrying far heavior loads at all paces, cavalrs horses inay be required to exercise their energies for dass together in bad as in good weather, and without being comfortably stablecl or cared for nfter the day's toil is ovor: the food being often scant5, and of bad quality at the same time. The hunters, on the contrary, rarely have more than two dajs a wicek in the field, and they are seldom overweighted then. They are not troubled with dead hamper on their bneks in the form of kit and equipment, as troop horses are, nor, like them, hare they to carry from 18 to 20 stone, unless specially selected by their size and strength to move casily with such a load. 'Troop horses cost 40 l. a-hend to buy ; hunters, to carry the weight they support, rould fetch severnl hundreds of pounds eacl. The allowance of forage for a hunter of this size is probably not less than 16 lbs. of the best oats daily, to which probably 1 or 2 lbs. of beans and some carrots will bo added, while 8 or $10 \mathrm{lbs}$. of cxcellent has supplements the grain. Kept in a warm stable, clothed, bandaged, and groomed in a manner to which the trooper is an utter stranger, and with only two dajs' work in seven, at the end of the hunting senson snch horses, nerertheless, often show marked signs of fatigue nnd wear.

Need wo wouder, then, that cavalry horses on a campaign should soon begin to break down, when taxed as hunters nerer sue? One chief cause for breaking down is insufficient food, and, therefore, though serious obstacles may arise to hinder ample supplies of forngo being obtained, ererything possible should be done to keep the horses well fed. Caralry must act with celerity and energs, in order to favourably influence the success of a campaign; and unless the horses are well attended to in the matter of forrge, their action must be weak and slow, and losses among them will be heavy.

Theso remarks apply more particularly to the horses bred in this country, to which a plentiful supply of good forage is absolntely necessary. Whether it is because thes aro not inured to hardship, to which thes aro indecel rarcly exposed at home, and seldom miss in meal, much less lose a day's ration, or that they are constitutionallydelicate, and suffer to an extraordinary degree when their ordinary allowance of food is diminished, certain it is that, unless they reccive particular attention in the matter of aliment on active service, they quickly gire in. In this respect they differ much from the horses of other countries, and especially those bred in the East. More powerful and fleet than they when well supplied with pabulum, they offer less resistance to the effects of short rations, and become of little use when recciving an allownce upe hich other races can undergo serere fatigne. It is true that our urses are never tested by expericnce of the hardships of war in their own climate, nor usually in a climate resenbling their own; and this may afford a reason for their 
being ensily rendered ineficient when scut on active service nut of this country, as climate at tirst affects horses more scriously than it docs meu. The fact remains, that unless rers well fed and cared for, our horses, light and heavy, hare a grent tendency to become feebleto lose henrt on service; our recent campaigns in South Africa and in Egspt and the Soudan afford ample confirmation of this, while our experience with other races shows that thes nre not so susceptible.

'Take, for instance, the small horses generally designated Arabs. It is wonderful the power of endurance thes displny when carrsing hears loads for long periods, and recciving at the same time a very sennty allowance of foorl. One of the most notable instances of this natural hardihood was afforded by the 19th Hussars in the Soudan, in 188.-S5, and deserves mention bere, as it is not ouly pertinent to the subject under discussion, but reflects great credit upon that cxcellent jegiment, and especially upon its then chief-the lamented Colonel Barrow-surely one of the most promising and accomplished caralry Officers our Army has produced.

The regiment was mounted on Syrian horses, whose average height was about 14 hands, and arerage age 8 to 9 sears old, thongh sbout 15 per cent. were more than 12 fears old. Somo 50 per cent. had been through the campaign in the Eastern Soudan with the regiment in the early part of $18 \$ 4$, and returned in a very exhausted condition; and about 10 per cent. had been at Tel-el-Kebir. In Juac, 1834, they were taken to Assouan from Cairo in barges, and remained there three montlis. In September thes wore marched to Wady Halfa, a distance of 210 miles, and these 350 were, in November, handed over to the regiment; all except some 10 per cent. being in fair marching condition. The regiment marched from Wady Halfa to Korti, about 360 miles, the average daily march being about 16 miles, not including lnits, which were for four clays.

The ration was supposed to be 8 lbs. of grain-barley or dhourra, and 6 lbs. of dhourra stalk; lut owing to scarcity, the horses generally reccired abont $6 \mathrm{lbs}$. of grain nud $10 \mathrm{lbs}$. of stalk. They arrived at Korti in good condition, remaining there for about a fortnight, and receiving about $8 \mathrm{lbs}$. of green dhourra stalk dails, instend of drJ stalk, upon which they improved. At the end of Decenber, 40 horses proceeded to Gakdul, 100 miles, and performed the reson. naissance duties of the column. The march was accomplished in 63 hours; 15 hours' rest was allowed, and then the return march was completed in the same time as the outrard one, except that 6 horses did the journes in 46 hours, the last 50 miles occupsing $7 \frac{1}{2}$ hours. During the 141 hours of the march, the horses were ridden for 83 hours. On Januart Sth the 155 s horses, and $127 \mathrm{men}$, with 8 Officers, crossed the desert with Genemal Sir Herbert Stewart's column; thero being an extra horse for each Officer, and 12 spare horses for tho men. The average forage ration for the first 10 days was from 5 to 6 lbs. of grain, with 2 gallons of water; 31 miles mero marched thils, not including one day's halt. When the first advanco ras made to Matammeh, the horses marched to the Nile without haring receired a drop of water for $5 \dot{5}$ hours, and only $1 \mathrm{lb}$. of grain. Some 15 or 
20 horses receired no mater for 70 hours. Between Jnnuary 20th and February 14th the horses receired no grain, but receired about 10 lbs. of dhourra stalk daily, or 12 lbs. of green dhourra or green beanstalk. Two days beforo marching they had 6 lbs. of grain cach. They performed outpost and patrol duty, averagring about 8 miles daily, and under these conditions they recovered from the effects of the desert march, though many were in a weak state. For tho first 75 miles, the horses had only 4 lbs. of grain and 3 gallons of water; for the remainder of the journey water was plentiful, and $8 \mathrm{lbs}$. of grain could be spared for each horse. Two marches of more than 40 miles cach wero made-evidence that the horses were still in a fit gtate. After two weoks' rest at Korti, tho horses marched strong and well to Dongola and other stations, receiving plenty of food and water, and after two montls' halt they were in quite as good condition as when they left Wady Halfa. The return march to the latter place-about 250 miles, was performed at the averngo rate of about 16 miles a day, with one halt for two days.

During this nine months of a linrd campaign, in which more than 1,500 miles were marched, only twelve horses perished from disease, though from other casualtics fifty-nime were lost. 'The weight carried by each of these ponies never averaged less than 14 stone, and during the last four months of the campaign the weather was very trying, and the scarcily of water was often sererely felt. 'The Inanalgement appears to hare been excellent; the horses wers spared as much as possible from unnecessary fatigue, the men nerer being allowed to remain in tho saddlo a moment longer than was needed; marches in column were aroided, extended line being adopted, and when picketed tho horsos had always plenty of room, and their heads to the brecze. 'l'hey were allowed to graze, on erery possible occasion, on the grass of the Baynda Desert, though it was too dry to be swal. lowed.

I think it is pretty certain that Linglish horses would not havo survired such an ordeal as this.

In India somewhat similar incidents hare been recorded, cavalirg horses having suecessfully undergone long and severe marches on small rations; and Darwin, in lis "Vogage of a Naturalist Round the World," mentions the grent endurance of South American horses, particularly descriviner a journcy he made, in which his horses had no foorl for firo days.

Whether our horses could be trained to undergo such fatigue and fasting is a question which cannot be answered offhand; bat it reuld be well not to depend upon their displaying mach fortitude in the matter of short rations in the field, but rather to make provision for thcir wants being supplied in no stinted manner. If their powers of endurance are not so developed as in some other races, jet they far excel these in other important respects; like their inasters, they possess exceptional qualities wbich aro most conspicaous when food is plentiful, and, knowing this, our aim should be to provide it in sulficient quautity and of good quality-whether the horses are in quarters or the field. 'To succeed in doing this requires more than

rOL. XXXIII. 3 I. 
ordinary care and attention on the part of those who are responsible for the efticiency of our mounted troops. Forago rations are as difficult to deal with, perhaps, as are the soldiers' rations-so far as quantity and quality are concerned.

Lieutenant-Colonel CoLrine: As somcone must make n start, with your permission I will make a few obscrrations. Ihe puper which lias becn read by Dr. Fleming is an extremely interesting one, but it is of a technical charneter, and, thereforc, is probably interesting only to those who take more or less interest in horses. If you take the paper as a whole it consists in this, that horses used in civil lifo in the country and horses belonging to people not in the army are fed according to she climate, accorling to the work they hare to do, and accurding to the scason of tho Jenr; but that in the Arany this rule is not obscred, and they are fed all the year round esactly in the sane way. Whether the paper is intended to bring that particular feature prominently forward or not I do not know, but I should fure thought that any man wlio was not blinded by innumerable rules of red tape would liare ncknowledged that that was common scnse, and sirould be obscrred both in the Army and out of the Army. I should like, ns a matter of information, to ask 1)r. Fleming whether these Srrian ponies, to which he referred, were entire, or whether there were any mares, and if so, what proportion of mares there were? 1)r. Fleming tells us that all horses in the Army, as they neccssarily would be the first called upon for actire service, should be kept well fod und in high condition, ready to take the fuld at a moment's notice. 'Iliat, of coursc, is perfectly right as to forcign armies, where they have to move by land; but is not there this to consider, that in England before the actire operations commence, the lorses would probably hare to travel some distance by sea, and if they were in too high a condition it would be more injurious to them than if they were in a lower condition, not so well fed, and softer? That is one of the grent disadvantuges that caralry now have to undergo in the English Amu-thes hare to trarel by sea, and they lose their condition eren if they hare it, and if their condition is too high they nre apt to dic. I must confess to being a little disappointed at the lecture. I came in hopes of hearing some proposal from Dr. Flcwing as to an improred method of obtaining the forge and of distributing it. I haso always thought, and still think, that the system upon which our cavalry horscs are fed is not either cconomical or judicious; that the forage should be purchased by the Arms. direct, without the interrention of any middleman; that there should be a store in a central position like $\Delta$ ldershot; that all ought to be chopped and mised, and then should be distributed in bags, say of $90 \mathrm{lbs}$., sufficient for threc horses or more in the caso of carales they do not get so much. The horses rould then get all that they are supposed to get, and you would bo certain that the quility of the hay and oats was really such as was paid for, in which case the taxpajer would benefit to the ertent to which the contractors now unduly bencfit.

Inspecting Veterinary Surgeon WT. B. ITatrens : I slould like to say uf few Trords with reference to Dr. Fleming's interesting lecture. I can, perhaps, answer one of the questions asked by Colonel Colrile, with referenec to the purchusing of forage. For some time past forage has been purchascd in dldershot dircet, by Oflicers of the Commissariat Department, and up to the present the sjstem has answered admirably. With referenco to horse fecding generally in the Army, I quite agree with the lecturer that it requires inrestigation and rerision, because I an quite surc that the lobit of fecding heary loorscs with the eawo reight of gruin and hay as light horses is wrong in principle. The leary horses are generally the fist to suffer in condition on a campaign, and, thercfore, require more food in proportion to their bulk than the lighter ones. At the same time I think that if, say, three scales of forage were adopted-I, II, and III-I, for hears caralry and draught horses ; II, for medium caralry; III, for light curalry, infontry, Oflicers' chargers, and so on-it would be quite euficicint, because I think the German s5stem is rery much too complicated. It is excellent in theory, but in practice it would hardly be found to be quite as perfect. Then also as to incressing the ration on the 
line of march, mentioned as heing adopted in the German Army, I do not quite see why hor:es should recciro an addition to the ordinary scale of ration whilo actually on the line of march, because the result of this extin feeling-improred condition and increised poners of enduranec-slould be, I think, present at the time tho lorscs are marcling. The cfret of giring cxtra food only during the period of jnerused exertion would be almost like giring a man a heary meul just before ho lato to run a race. It is better to prepare horses for the line of mareh by com. pencing the extra rations some weeks before they are required to etart. As regards the quality and weight of the oats supplied to Army horees, I ccrtainly think that the grain should not reigh less than 40 lbs. tho bushel, because in nearly all samples of forcign oats-and the grain purchased for the Army is principally of foreign growth-there is an admixture of sceds which are not only innutritious, but in wany cascs delclerious in their nature. I hire alwajs been an adrocate for cruslied oats. It has been observed by many Officers in the Army that the issuo of crushed oats on a camprign would be a matter of diffieulty if not an impossibility. I think, on the contrary, that there would not be the slightest trouble about it. Crushed oats are consideribly more ensily digested and nssimilated than whole outs, and $\mathrm{I}$ am of opinion that 10 lbs. of grain in this form is equal in nutritive value to 11 or 12 lbs. of uncrushed oats. That form of forage bnown as " main cake" is moel excellent of its bind, and ccrtainly is far casier of transport than the same weight of whole oats. With regard to the loss of condition of horses on ecrvice, my experience of campaigning has taught me that caralrs horses are geserally the first to fall away, particularly those of heary caralry; therefore it is quite necessary that our cavalry horses should be kept up to the highest standard of condition at all times. Of course wo know perfectly well that prior to embarking horses for a loni sea royage, it is very necessary to niake an alteration in their diet, in fuct to prepare them for a period of inactirity; but if animals are embarked in a high state of health and rigour, the losi of condition during the rojage will not be great, und nill soon bo recorered. With regard to the Egyptian horses nentioned by Dr. Fleming, I liad some experience of this class of animal in the Soudan, and thoroughly agree with crery word that he has eaid. They were principally stallions, and these liardy little aniuals certainly did their work wonderfully well without suffering from priration or climatic infuenecs to anything like the ertent experienced by the English liorses, although often placed under less farourable conditions.

Coloncl-F. J. Graves, 20th Hussarz: Colonel Colvile expressed his regret that the lecturer liad not made any proposition. Although there wat 3 no direct proposal mate, I think it is erident that a useful proposition was made by inference, and I think it is rery necessary that the whole question should be investigated with a riew to the proper proportioning of forage to the horse's size, work, and to the scason; and I am quite in agrecuent with such a proposal bcing curried out. It scems to me to be absolutely absurl that a loorso at 15.2 currying a hussar of my own rewinent should be fed all the ycar round upon $10 \mathrm{lbs}$. of oats and $12 \mathrm{lbs}$. of hay in the sauc way as a horse of 16.2 , and perhap $300 \mathrm{lb}$. heavice in total inass, carrying possibly from 21 to 22 stone; it scems ridieulous on the face of it. There is a rery interssting comparison drawn in the lecture between two batches of artillers, both before and after eighteen days' hard work. In my own reginent at Norwich the other day, an csperiment was carried out, not before and after hard work, but positirely during a time of what one might call comparatire idlencss. We had some sirty odd horscs, one squadron, put under cxperiment. I am eorry to say the instructions with reference to carrsing out the experiment wero so limited that I do not think the result of the experixent or the reports thereon will be helpful in any way, und for this reason : the instructions conreyed to us were simply to report as to the adrisability, us I gatliced, of a permanent reluction of 2 lbs. in the geneml ration of onts. This experiment was carricd out in the furlough ecsson when wo probably had not cnough uien to groom the liorses, let alone exerciso them, and when there was rery little or no drill done, for the simple reason that we are forbidden to $g^{\circ}$ on the drill.field for frar of cutting it up; and under the further ridiculous condition that erery day the horses did happen to go out on outpost cluty on the roads, thej were to hare 2 lbs. of oats extra. The sum total was this : that 
just as tho horses, after their cightecn deys' work in these tro ballericz of artillery, lost a certain amount of weight, so the whole of the squadrons, with the exception of six liorses, lost on an arerage $35.5 \mathrm{lbs}$. after two nonths. Thes were wcighael before the commencement of the experiment, nfter the first month, and also ifter the second month lad concluded, and the result in the cnd was an average redue. tion, ns I say, in the whole equalion, with the exception of sir horses, of $35.5 \mathrm{lbs}$. The six horses had gained something under 6 lbs. apicec. What is to be learnt from that cxperiment? The horses had been doing comparatircly little work; they were rery fat; our stables at Norwich are clark, and that contributes tornards the accumulation of fat, I think. They are also warm, and there is another induecment to fat. The simple lesson I learnt from that cxpcriment wus that I considered tho horses had got rid of what was positirels an incubus to them, and, if I may eaz so in the prescuce of the lecturer, wliat I consider, if they were going on ecrrice immediately, rould be n danger to then, beciuso horses grossly orcrloatled with fat are certainly, to wy mind, more liable to inflammatory diseases than horsos in fairly good working condition. Comparison lns been made of the foraging of our Army horecs with those of the German, lirench, and Kussian armics, and, looking through the lecture yesterdas $I$ gathered that in those countries from which comparisons hare been drawn, tho nutritire ralue of the ration, as a whole, is considerably ligher than ours. I began to think why it should be eo. I think it is for this simplo reason, which docs not do us, as a scnsiblo people, much credit, that with tlec exception of Aldershot, the Curragh, Dublin, and one or trso other statione, it is impossiblo for our caralry to carrs out efleient caralry instruction in tho way in rhich it is possible for the German, French, and Russian urmies to carry out their instruction, and for the simple reason that we hare not the ground to do it on. Von Schmidt, the great ciralry instructor in Germany, insists on long ax?vances of two or three miles. Whero can we get that at Norwich, Brighton, Shorncliffe, Lecds, Manchester, or any other such place? Wo are put into a reformed turnip-ficld, and are supposed to do erergthing it is possible to do with caralry, confined as we are in such a spot. 'Therefore it would be absolutely necessary that the nutritire ralue of rations in Germany and clsenhere slould bo greater than with us. Although wo hare a less quantity giren, I am quite clear that in times of peace, and especinlly during the idle season, the winter season, when drill grounds are nct arailable, our horses are orer-fed. I am quite clear in my own mind from what I hare seen that thes are orer-fed at that time, and possibly during the mancurring scason, of which we hare had too little in this country, they are under-fed. If they were giren the forage during the idle timo at a reduced rate I am quite sure the Gorerument would allow us to draw the balence during tho hardworking scason, and there would be no extra expense to the country. I lo not think that there is ans. thing which should present that being made a definite proposal. The cale that was referred to in the lecturo is simply the horses' natuml food under compression. 9 lbs. of that calce and $8 \mathrm{lbs}$. of has produced an cqual result at Aldershot to $12 \mathrm{lb}$. of oats and $12 \mathrm{lbs}$. of has, simply becausc it is crushecl. Therefore, I think, if it could possibly be done, that the oats issued, especially at the out-stationg, while they might be reduced in quantity, might with great ndrantage be crushed. We lare gone a little way in that direction in uns omn regiuent. We have nor four chopping machines in the regiment at Nurwich, and if suggested about a mouth ago that defnulters and the few men now and then in the cells, instend of haring shot and pack-drill, should be told off in sniall partics under the orderly corporals of troops to cut the wholo of the necesiary chop for the troops in the morning. It is now done, and with rery grent adrantage. Ono great adrantage $I$ would litso notice. The horses eat their food erer so much moro slowly; there is no bolting of the food and ecattering it about all orer the stalls to be troduen down and apoiled; but the horses stick their heads into their mangers and munch away, quictly turning orer the chopped has, picking out the oats, and then finishing up with tho chop that remains. It takes a horse one-thirl or half as long again to cat his food in the stable, with chopped has uncler these conditions. I do not see, if we hare liay-cbopping machincs, why we should not do something out of the cantecn, or soune other fund-tho Gorernment I do not suppose will pay for them-in getting some ont-crushers. I am quite sure it rould be impossible to get crushed onts from 
the contractors in a satisfactory was. There is no article of consumption for the Lorse which is so aclulterated as oats bought crushed, but to buy onts in the ordinary was and crush them afterwards is quite feasible. 'There is another point I should lite to touch upon. Dr. Fleming in suggesting by inference the changes indicuted and the necessary inquiry-perhan 3 being in an offial position in the matterfonght rather with the glores, but I think thero is one point ujon which we ought to hit out pretty bard. There is no article paid for by the taxplayer, I beliere, round which circumstances of corruption of the grosscst form circlo so much as the eupplying of our horses with forage; I am quite elear of that. I could keep this meeting rery much longer than tho ten minutes which $I$ an allowed by giving you the ipsissima cerba of things which hovo come under my own personal knowiedge, which I hasc run to carth, in the way of corruption in this matter. 'To takc ono rers simple case, which unfortunately camo to my cognizance too late to act upon. At a certain station and at a certain time crers singlo Offecr's groom in a reginent was in reccipt of a shilling a month from a certain contracloo. I sliould fiko to know whero thint shilling a month camo from? It came out of the horscs, it was sared out of the weight giren to them. I know of another occasion whero again through being unable to get eridenee, wo were foiled; in one day a thousand pounds weight of struw was issued short of what ghould have becn issued. With regard to that rery cake before you which I inrented, I got a letter one day from my inanufacturer, telling me that when IIis Rogal Highness had ordered a certain number of horses at Ililsca, which wero in rery bad condition, to bo put on that calo to ece how thes did on it, about o week alter this cale was issued, two quartermaster-scrgeants of the troops stationed thero camo into the office. They snid "Good morning" to my manufacturer. Hc said, "What can I do for rou ; wliat is your businces?" "Wrll," they said, "we have come in the ordinary way of business. Fou bare just got the contract for the supply of our horses, and wo thought we would just look in and sce how things were going on ;" and so on. "What do jou mean " ho said. "Well," eaid the spokesman of the tro, "it is usunl that some sort of conmission should be giren in order that thing 3 mas be made to go cass." MIy manufacturcr liad very special instructions from me on this point, and ho replied, "I do not know whether you know it, but Captain Grares" (I was then Captain) "is the inrentor, and wo are bound to him under articles of agrecment, and anjthing that is dono in connection rith this enke we must put before him first." Mry manufacturer wrote to me giring me the vers worls t tint had passed, and I rrote back, taking steps that I flattered mysclf put a stop to that business there and then. The corruption that gocs on with refercnec to the supply, Loth as to quality and to quantity, is something surprising, and ought to be mads public and inrestigated in the most thorough rag. We know the difficulty of getting eridevco on this point; men will give jou a raguo report, they will say something about so and $\varepsilon 0$, but ns to coming to tho front and stating it before a court-martial on oath, it is quite another thing, and it is rery hard to get such cridence, and I beliere tho authoritics aro heartils sick of tho job. I hare now; Sir, a definite proposal to make which lans been on my mind for some considerable time. Shortly it is this. When a subaltern joins a caralry regiment, he is supposed to hare been positively born in a butcher's shop, in a baker's shop, in the middle of $n$ hnyfield, and of an oatfield; he is supposed to know good meat, good bread, good potatocs, good oats, good hay, good struw, good crerything. ITe goes on witl tho ordinary orderly Olicer of the day to be tauglit his duty. After a very little timo lic is put on duty for hiniself; he has to go down and to pass the rations, and a lot he knows about them! Ho goes to the gate, and there you will see a boy of about four or fire month' Eerrice, rery often less,--when wo aro hard up for Oficers for dut5, - passing in hag, and if jou werc to ask him the name of one single grass, as I did one fellow of my regiment, handing him a small tuft of Italian rye grass, ho docs not know it a bit. Thes haro to pass this stuff in, and thes know no more about it than the woman in the moon, if there were such a person. I beliere firmly if the thing is to be carried out eatisfactorily in the ray of supply as to quality and quantity, the proper men attached to the caralry and artillery and mounted corps who ehould pass tlicse urticles, are the Oficers of the Velerinary Department thewselres. 'There are a good many members of the Veteriuary Department hero, 
and I hope they won't think I am trying to urge the necessity of increasing theie dutics, but rather that they will take my proposition as a tribute to their greater knowledge and higher clucation in this matter. I adnit msself that I do not know enough about forage now, and I would bow to the decision of a properly qualificd reterinary practitioner in a matter which so urgently requires inrestigation as this docs. I beliere armingements could be made in euch regiment, at each station, so that the forage should be presented at a certain time when the reterinary OMcers were ou the spot without necessarily increasing their duty. After that was done it could be distributed to tho stables in the ordinnry course, but for young and inerperienced subaltern Oflicers to hare the power of rejecting or passing that which constitutes the mairstay of the horso's vigour, and the mainstay of the horse's usefulness, is to my mind utterly absurd. It is an important subject, and I do hope and sincerely trust that the Gorernment may.be led to tako some steps to put it on a better fooling. I do not think any better service las been done of recont years in this direction than that of the lecturer in bringing it forward to-dny.

Colonel Jour Frrer, C.B.: This is a rery interestiog subject. There are one or two points on which, if you will allow me, I should like to mate a remark. I think we are rery much indebted to the Principal Veterinary Surgeon for having giren us such a rerg lucid, interesting, nud uscful paper. IIc was called to account for not having produced eomo plan or proposal for eerrice and other matters, but that is exactly what ho riants to heis us talk about. I think wo aro nll orrecd on one thing, and that is, that we in the l3ritish Army haro been moving for mnny years on mhat I maj describe as the rule of thumb with regard to the horse ratious. I am of opinion, and I think many others without the least braggadocio will say the same, that we hare rery little to learn from anj Continental Army with regard to the feeding of horses. I had the pleasure of trarelling last ninter in a great many of the capitals of Furope, and I cannot conceire anything more superior than tho borses in London to thoso that you ece in other Fiuropean capitals. That is not caused by the brecding of the horses only, but by the care with which they are attended to and fed. I cannot help thinking we should do rery much better by taking a leaf out of the book of some of our own grcat currying companies which the lecturer has rery properly brought forward to.day. Our rule of thiumb is this, that re giro oats, li25, and water. The oats are mostly foreign, nnd chiefly Russimn. You may get 40 lbs. to the bushel, but with this rery often a very thick-shinned ont, which will weigh hears, and I suggest with all humility that it would be far better to hare a mixed food for curalry aud artillery horses, such as we see in eome of the rations of the great metropolitan companies. I hare had practical experience of somo of these companies, being rather largely interested in them, and I can safely sey that no horse working citlicr in the London General Onnibus Compans, or the Road Car Company, doing the work that they do, could possibly lixe on oats and hay alone. Gire him as much oats of the class we feed our troops on as youl like, without other grnin, and ho will fall away in condition. Bulk also is neccssury for condition, but I say we requiro to vary the ration by giving other grain with oate, and I should like to see that done rers much. 'The nest point we should inquire into is this. Does our present ration fulfil the requirements of our mounted branches in quality and quantity, or do wo get as much out of the present ration as these great compinics do out of theirs? Iy opinion is we do not, and for this reweon, that we do not, as they do, chop and crush our food. 13y chopping sou got the rery cisence of the hay and the essence of the oats; jou get, in my opinion, quite 30 per cent. more out of chopped hay and oats than jou do by giring it to them whole. There is one little matter which has not yet been mentioned, it is rery chesp, and that is water. Water is the rery esecnce of condition, no horse in the world will keep in condition unless you continuslly water him. "Water frequently" ought to be written up orer erers troop stable door-water, water, water. 'That is the one grcat sceret of condition on a linc of march or campaign, that the horse sliould be wntered as often ns possible. That may be outside the present question, but it is so. The lecturer said that the first action very often decides a campaign, but I think he will also agree with me that that army whoso caralry and transport stay the longcst usually wins the campaign. Thercfore tho stajers are those which we hope to sec iv our caralry, and cannot be uttained without con- 
tinuous care and attcntion in the fecling of the horse. I repent, the two things we rinuire are: 3st, that the ration should be raried wisen pricticable; 2nd, that wo ghould chop and crusle crerything if possible by steam pooce. I belicro these two points to be mainly necessary for the maintenance of condition in our horses.

'The Cirsinssax (Sir 13cauchomp Walker): I lasro little to enj creepting that I rery much agree with the Principal Veterinary Surgeon in what he has told us to: (as. I sliould like to ask Colonel Grives what 2 lbs. of ration disl you take off2 lbs. off the liay or off the oats?

Colonel Grites : Off the onts.

The Cunarirax: And still gare the same amount of hay. Thero is no doubt that horscs require a certain aunount of fortge in bulb, at least ous English horses do; but onc cannot help obscrring-knocking about the workl as I hare done for a great pialiy scars-how totally differently the varions races of horses require to be fed. In the German Army, to which Dr. Fleming has alluded, with the cxception of the yery big horses which are allotted to the cuirsesier and lancer regiments, nearly the whole of the horses of the old 'Prussian Army cane from liast I'russia, where they harc brecling cstnblishments of their own, and the only horses bought were the bigger horses, which are bred chichy in North Germang and Meclienburg. But there is a rery strong infusion of Amb blood in the horses bred in Eist Prussia, and I had no doubt, during tho long time I was in that country, that agreat deal of their hardihood and endurance aroso from that circumstance, becausc it reminded me rery much of the horses with a more Eastern blood than our own which $L$ had seen in other countrics. It was cst mordivary in Spain on how little horses did very lend work indeed : barley and chopped struw were the only forage we crer gare tho horses there; and I believe in Arabin the horses do an cnormous amount of work on a quntum of forage which people in England would hardls belicre in-positircly mere handfuls. Fou cannot in the Arabiau desert, of course, hare angthing in tho shape of lass; it really is nearly ull grain, und a rery small amount; I do not bnow whether Dr. Fleuning can tell us.

Dr. Finjusc : 4 or $5 \mathrm{lbs}$. of barley.

if The Criaryax : There is a question I should like to ask Dr. Fleming-it reminded me of olden times-and that is what he thinks of sheaf birles as forage for horses, I beliere anj grain mas be giren, I beliere eren wheat on an emergeney mas be giren to horses, if it is giren with the shenf straw. I had a remarkablo expericnce of what slieaf barley can do while we were lying opposite Varna, preparatory to crossing for the Crimen. My then clief probably knew more about fecding beasts than anr man in England. IIe liad for a great innny Jears lookcd after lis own property in Iruland, and I beliere had fed rery largely himsclf for the Irish markets. One das he announced that the Commissary-General had informed him that we had no more forage for the caralry. Whith on curth was to be done? Ile eaid : "It is no use putting the horses on too small an allowance. IIorses must liare a certain amount of bulk. If you do not gire bensts a certain amount of bulk they are sure to go down." He said : "There surely nust bo sowcthing in the country." Now I had had a habit on the days I was not on duty of riding all orer the country south of that part of Bulgaria tonards the Malkansi and I hind scen that the whole country was covered with ripe crops. I told Lord Lucan this. Ho said, "What lase you seen?" I said, "I haro ecen quantitics of barley, and thes are just beginning to cut, in fact." I said, "If you will only look outside the tent jou will sce ono ficld quito close to our canip." Ho eaid, "You come down with me to.morrow morning and we will sec the Commis: sary-General." We went. The conversation was rather a curious one, and at last Lord Luean said, " MIy dide-de.Cawp tells me that there is plenty of forage in tho country, there is plenty of forge that can be bought. Now I lnow forago giren in the shenf can be usch, eren if it is barley, which is otherwise a rery heating grain." "Ol!!" Eaid the Commissars-General, "that gentleman suys there is forage in the country, docs Je?" Iord Lucin, with the slarp temper which ho generally sliomed when he was being opposed, saicl, "I's, if I buy the forago will you pay for it?" "Ol yes," said the Commissary-General, "I will pay for it." I bought 4,000 rations of barley beforo I eat down to dinuer that day, and for nearly thee weeks $I$ rodo all orer the country with money in ms pocket and bought 
barley for our horses, for that portion of the forec which had not gone up the country, and as far as my recollection goes-I was not doing regimental duty at the time, therefore I could hardly speak to it as well as some otlucrs-tho horses did extremely well and timrore on that forage. Whether it would hare answered for a continuanco is another qucstion, but I was particularls anxious to clicit a remark on the subject from Dr. Fleming. Water, as he says, does not form part of the horse's ration, but I wish ho lial gaid something about water, becauso I look upon it as nearly as important as the food. 'Ihere has, I belicre, a rery good custom been introduced in all new stable fittings, and that is of haring a receptaclo for water which ean be bept permanently filled. It wass not so in my day, anci I am ufraid it is not rerg mucl the case in our barracks, but I lope as we aro building new barracks occasionally that it may be introduced, because I an conrinced it is a rers great point. I also beliere runniug water to be about the best water we can gire a liorsc. I remember being with my troop a good mans Jears ago during an clcetion in Ireland, and I obscrred that the horses fell off after the first two days. In consultation with wy scrgent-major, ns I belicre crery Captain ought to be as much as he possibly can, he eaid, "I think if wo watered at the river you would fud a rery considerable iwprorement." Wo went down and watered nt tho river and I took the horses buck to Watcriord looking rery much better than when wo left, which I rery much attributed to watering them at running water crery morning. I au ofraid that altogcther our stable fittings are unch in the old style. Of all bad ways of fecding the has, that of the high rack is perhaps the most hurtful : there is a great deal of waste and the horse's forclocks and ejes get filled with dust. I think in prirate etables now-a-days they are mearls all low feeding. I alwass crushed ms omn oats. I was a very poor wan and rery fond of hunting, and had rery few horses. I tried to get as much work out of them as I could, and I always crushed the oats from the first day it was brounlit to my notice. I hope we may clicit from Dr. Fleming some opinion as to how he would modify our ration, becaluse I alwass felt the reuson whJ $\pi \mathrm{c}$ liad $12 \mathrm{lbs}$. of Liy was that there was 80 much waste and it was for the purpose of giving the horse from 8 to $10 \mathrm{lbs}$. realls to cat. I had one very good rule in my troop during the years I commanded one, which was that if I did not go and look in on the afternoun, wy subaltern or some non-com. missioned offecers did and stirred up the stablemen to going round and picking up the las that was pulled dorn and put it back again, because there is no doubt that in feeding from ligh racks there is an cnommous waste of hay.

Colonel Fryer: One-third.

Tho Cincinasax: That reduces it to 8 lbs. The rest gets trodeden into the litter, and cntirely apoilt for consumption. Certainly $10 \mathrm{lbs}$, of oats is little cuough for the bjg horses we hare in our Serrice, if they are to do hard work. Jly hunters had 16 lbs. always, besido it being crushed, and beside a handful of beans in cach feed. I think we are all rery much indebted to 1)r. Fleming for haring giren us these two lectures. I only wish there had been more Offecrs of my old branch of the Serrice and of the artillery to listen to them, and to gire us tho adrantago of their cxperience, and by so doing to clicit replies from Dr. Flewing, which are suro to supplement tho information lie has giren us.

Colonel Colvine: In the omnibus companics' stables the horses all hare a receptacle in front of them for water, which is always full, and they drink how and when they like.

Dr. Fresura: Mr. Chairman and gentlemen, I am rery pleased indecd with the recption you hare giren my lecture. The paper itsclf is rather disjointed; the materials had to be collecled from rarious cources, and some of them were derived from my oun experience. Notrithstanding, the subject is a dry one, if you leare out the water, and it is a difficult thing to make it interesting to peoplo who are not rery cutbusiastic in the matter of horses and horso fecding. I an only sorry we hare not had a larger discussion on the subject, because from my peculiar position it is a diflicult thing for we to mako ony proposals, and I was liopeful that the discussion which we might hare had to-day would have inforued me, to some extent at least, as to how to procecl in the matter of having an inrestigation into the foraging of our horses. Ferertheless, so far us the thing has gone, I an satisfied. I am extremely eatisfied indeed with the remarks whịch hare been made, and I 
Ely:1l try to reply to the questions put to me to the best of my ability. The firat question nsbel was as to the Srriau horscs. The horses were entire. I do not think it mokes much difference nith regard to cndurance : we lave prored in India that the opposite conditions are just as good. It has been prorch bf the experience of caralry Oalecrs iu Iudia that horses which rrere not cntire worbed just as well as those which were, aud did not fight so much with each other. MIJ cxperience, in China cspecially, of a number of Japancse animals we lad, was that they were perfect brutes, and, I think, it is the experience pretty well of creryono who has to do aith horses, that they are much better when they ure not entirc, that their fighting and injuries nro rery fcw; and not only that, but in reconnoitring, cspccially at night, entire horses will neigh, and if the enemy is within 2 or 3 niles ho is suro to hear them. With regard to horses on shipboard, it is a matter for regret thint our country is an insular country, so far ns curalry is concerned; because it is absolutely necessary that caralry liorses should be in first-rato condition. If wo hare to put horses on shipbourd, of course we run the risk of their good condition ratlrer detcriorating on a vosage; nercrtheless, I contend tliat a horse in good con. dition is in a better state to withstand the rojane than if he were not in good condition. A liorso sent on slipboard lequires all the resisting power of good wuscles and heart to endure bad weather at sen, and tho horses which enffer most are tbose which are not in condition-that is, fat horses which hare not had surf. cient cacrciso before being cubarked. The caralry horse should always bo in a fit ftate for a royage, and the lorse in the fittest state for the royage is in the fittest state for actire service. Tho rations, of course, liffer from those which the horse get 3 on elore : they are adapted for the horse being bept in one position without crereisc. With regard to the contract system for forage which now prevails to a largo extent in this country, that was discussed in my lost lecture. I know the system is a most obnoxious one, and all who hare paid attention to it know that there is no part of the contract system in the British $A$ rmy more exposed to cheating or robbery in crers form than that which pertuins to foraging, but tho problem is hor to get rid of it. Al out-stations and emall detachwent stations it mould perhaps not be expedient to send Offeers to purchase tho forage. I think perwission ought to be giren to the Oficers who command regiments and detachments to buy tho forage at first hand; but that again would cutail special hnowleclge, and that bnowledgo erery Officer docs not possess, though there is no reason why ho sbould not. Livery Othecr who has to do with horses ought to know good forage from bad, and be able to estimate the ralue of forage in the market. If the system of contract could be abolished, and Gorcmment could buy direct from the producer, I think it would be much cheaper for the country and rery much better for tho horses. With regard to the reduction of the ordinary ration, this has becn tried. I myself made the preposition, sccing tho amount of danage our horses often sustuin in the stables during the winter season, and especially at outquarters. In one of the caralry regiments in which I ecred, it was our custon to diminish the allowance of oats in winter, and to gire what wias eared to the horses during tho summer drills. Of course that was not always ensily donc; largo barrels lad to be prorided, and sometines we got the order to march beforo the summer drills began. But I was mored more particularly to make tho suggestion from the fact that the casualties in winler in stables aro rery often much greater than in sumner, from the fact that tho borses aro fed in winter ns in sunmer, and not getting the same amount of work in rinter, they atnuso themsclres by breaking cach other's legs. It was proposed that during the winter scason 2 lbs. of hay should be substituted for 22 lbs. of oats; that, instcad of $10 \mathrm{lbs}$. of oats, $8 \mathrm{lbs}$. of oats should be given, and instead of 12 ibs. of hay 14 lbs. of hay. The reports as to tho result were of tho most contradictory kind. One regiment had not been put on this altered ration long, before it wes noticed that all the Lorscs were starredlooking and wesk, and a rery great sensation was caused. At other stations at the cnd of a certain period the reparts wero farourable so far as the liorses were concerned; they were in good licalth, and the casualtics ferrer than uzual. From other stations, again, it was reported that the horses liad lost condition, and rere altogether unfit for the spring drills. So that the reports would tend to proro that it is not safe to reduec the present ration, either in summer or winter. This I do 
not agree with. I have already said that tho harscs should be fed according to their work: beyond a certain anount thes should reccire forage in proportion to the amount of excrtion thes undergo. I think if loorses are standing in stables, doing littlo work, thes ought to haro fener outs; more hay should be allowed if necessary, but some of the stimulating food should be withheld. Oats should be given in largest quantity during hard work. I think the present ration might be improred, so far as the inaterials are conecrned. To keep horses upon oats and hay all the year round must be unsatisfactory for them. Some rariation wight rell be unade, and wo hare the example of large companies which cmploy heary and light draught horses to show that $\Omega$ mised ration is necessary and beneficial. If these horses wero fed all the jear round as our troop horses are fed, I lo not think they would perform the same aunount of work they now do. We all know that a mixed dict is neccssary for oursclres, nnd it must be the same with the horse. I think if the oats were mixed at interrals with beans or maize eo as to make a variation, it would be all tho better; but, nerertheles, I do hold that horses should bo fed in peace-time as jou intend to fecd them in war-timo: therefore, if you gare them a mired ration in peace-tine thes should also hare it while on active scrrice. With regarcl to sheaf wheat or barley, there ia no doubt when the grain is pretty well ripe and the straw dry it may be used as food; but if the head is grcen and tho stalk contains much eap, eo that there is too much rooisture, it will damage the horses. Of courso wheat or barler giren to liorses unaceustomed to it is not the samo as onts. We hare the fact that in Sonth Afrien English lrorses, when they first arrivel there from England, were fed upou "oat-liay" and did. well, and there is no doubt that the unripe grain given in tho straw is muel safer than the grain itsclf. With regard to water, of course that is only part of the borse's ration on shipboard; it is not taken into consideration in conncetion with forage, cither at howe or in the ficld. It is most important, ns lias been eaid, that horses should have us much water as they can drink, and they ought to hare water always before them whenerer possible. If horses are kept from water at long time, they take an inordinate quantity, which is likcly to do them harm, and I an extremely sorry llat cren in our new barracks the water trough, which is now so common in the stables of civilians, is not present as a plart of the nanger fittings. We hare ono improrcment, lowerer, the rack is on a lerel with the inanger: the orerhead racks ure abolished; still I should be rers glad indecl to sec the water trough alongside the rack and manger. The modification of ration which we might hope for should be something on the scale of the German Aruy. As already stated, horses should be fed according to their size and the amount of Tork thej do. I think there ought to be a peace ration and a war ration. A light caralry horse reighing 500 lbs. cannot regiuire, and thercfore should not recire, the same amount of forage as a horse weighing 1,200 or $1,400 \mathrm{lb}$. A horse standing in a stable, well groomed and kept warm, does not need so much fool as a horse standing out in the open, exposed to the weather. I think there ought also to be a garrison ration and a maneurring or ficld ration; when the rork is inordinately sererc, let the ration be still more incrcascd. Tho German scalc of rations is, I consitler, a good one, and it is well proportioned to tho horses and their work. You will ece a great dirergency between the German and French rations. The Frencli mounted corps for some years hare been complaining about the underfecding of their horses, and somo experienced Oafeers of caralry in tho French Arny say that their defeats by the Geruans were largely due to the French horses being underfed and the Geruan horses so well fed. This point is noteworthy, becauso if you compare the two scales of rations you will find a rery great difference. I do not think I have anjthing more to say on tho inatter. The discussion has been satisfactors, but I am eorry we hare not had a larger attendance of experienced Officers, so that we might arriro at somo definite conclusion as to really what the forage rations should be.

Tho Crisnjax: It ouly remains for me to ask you to cmpower we to gire Dr. Fleming a vote of thanks for his excellent lecture. 